\title{
Genetic characterization of Brazilian bovine viral diarrhea virus isolates by partial nucleotide sequencing of the 5'-UTR region ${ }^{1}$
}

\author{
Adriana Cortez ${ }^{2}$, Marcos B. Heinemann ${ }^{3}$, Alessandra Marnie M.G. de Castro ${ }^{2}$, \\ Rodrigo M. Soares ${ }^{2}$, Ana Maria V. Pinto ${ }^{4}$, Amauri A. Alfieri ${ }^{5}$, Eduardo F. Flores ${ }^{6}$, \\ Rômulo Cerqueira Leite ${ }^{3}$ and Leonardo J. Richtzenhain ${ }^{2 *}$
}

\begin{abstract}
Cortez A., Heinemann M.B., Castro A.M.M.G., Soares M.S, Pinto A.M.V., Alfieri A.A., Flores E.F., Leite R.C. \& Richtzenhain L.J. 2006. Genetic characterization of Brazilian bovine viral diarrhea virus isolates by partial nucleotide sequencing of the 5'-UTR region. Pesquisa Veterinária Brasileira 26(4):211-216. Faculdade de Medicina Veterinária e Zootecnia, Universidade de São Paulo, Av. Prof. Dr. Orlando Marques de Paiva 87, Cidade Universitária, São Paulo, SP 05508000, Brazil.E-mail: leonardo@usp.br

Nineteen isolates of bovine viral diarrhea virus (BVDV) from Brazil were genetically characterized through partial nucleotide sequencing and analysis of the 5'UTR region. The isolates were grouped as BVDV-1 (11/19), BVDV-2 (6/19) or "atypical" pestivirus (2/19). Among the BVDV-1, eight isolates were classified as subgenotype BVDV-1a, whereas most ( 4 out of 6) BVDV-2 belonged to subgenotype $2 \mathrm{~b}$. Two isolates from aborted fetuses were not classified into any genetic group, being considered atypical BVDVs. Genetic diversity among Brazilian BVDV isolates may be responsible for vaccination and diagnostic failure and therefore may influence the control strategies for BVDV infection in the country.
\end{abstract}

INDEX TERMS: BVDV-1, BVDV-2, Pestivirus, phylogenetic analysis.

RESUMO-- [Caracterização genética de amostras brasileiras do vírus da Diarréia viral bovina através do seqüenciamento parcial da Região 5'UTR.] Dezenove amostras do vírus da diarréia viral bovina (BVDV) foram caracterizadas geneticamente através do seqüienciamento parcial de nucleotídeos da Região 5'UTR. As amostras foram agrupadas em BVDV-1 (11/19), BVDV-2 (6/19) e num terceiro grupo de amostras denominadas "atípicas" (2/ 19). Das onze amostras genotipadas como BVDV-1, oito amostras foram sub-genotipadas como BVDV-1a, enquanto que a maioria (4/6) das amostras de BVDV-2 foi agrupada como BVDV$2 \mathrm{~b}$. Duas amostras provenientes de fetos bovinos abortados foram classificadas como atípicas, não BVDV-1 e 2. A presença da

\footnotetext{
${ }^{1}$ Received on June 8,2006 .

Accepted for publication on July 25, 2006.

2 Faculdade de Medicina Veterinária e Zootecnia, Universidade de São Paulo, Av. Prof. Dr. Orlando de Paiva 87, Cidade Universitária, São Paulo, SP 05508-000, Brazil. *Corresponding author: leonardo@usp.br

${ }^{3}$ Escola de Veterinária, Universidade Federal de Minas Gerais, Cx.Postal 567, Belo Horizonte, MG 30123-970.

${ }^{4}$ Instituto Biomédico, Universidade Estadual do Norte Fluminense Darcy Ribeiro, Av. Alberto Lamego 2000, Campos dos Goytacazes, RJ 28013-600.

${ }^{5}$ Centro de Ciências Agrárias, Universidade Estadual de Londrina, Cx. Postal 6001, Londrina, PR 86051-990.

${ }^{6}$ Centro de Ciências Rurais, Universidade Federal de Santa Maria, 97105900 Santa Maria, RS.
}

diversidade genética de BVDV detectada nas amostras estudadas pode ser responsável por falhas vacinais e de diagnóstico e deve influenciar nas estratégias de controle do BVDV aplicadas nas diferentes regiões brasileiras.

TERMOS DE INDEXAÇÃO: BVDV-1, BVDV-2, Pestivirus, Brazil, análise filogenética.

\section{INTRODUCTION}

Infections of cattle by bovine viral diarrhea virus (BVDV) are widespread cause of major economic losses to the cattle industry (Houe 1999). Clinical symptoms may involve the reproductive, respiratory, immune, and gastrointestinal systems, with signs that may range from disease with high mortality rates to asymptomatic infections. The latter is observed in most cases (Pellerin et al. 1994, Ridpath et al.1994, Baker 1995, Fray et al. 2000).

BVDV is an enveloped RNA virus that belongs to family Flaviviridae, genus Pestivirus. The viral positive single stranded genome of approximately $12.5 \mathrm{~kb}$ in size contains a single open reading frame (ORF) flanked by two non-translating terminal regions, named 5' and 3'-UTR. The single ORF is directly translated and gives rise to a long polyprotein which is co-translationally cleaved, originating 10 to 12 mature viral proteins (Collet et al. 1988, Meyer et al. 1989).

Isolates have been subdivided in genotypes BVDV-1 and BVDV2. These were further split into subgenotypes. To date, 11 
subgenotypes of BVDV-1 (Vilcek et al. 2001) and 2 subgenotypes of BVDV-2 (Flores et al. 2002, Vilcek et al. 2004) have been described.

Genotyping and subgenotyping of BVDV isolates have been accomplished mainly by the analysis of 5'-UTR region, since it is highly conserved among pestiviruses (Ridpath et al. 1994, Sandvick et al. 1997, Ridpath \& Bolin 1998, Letellier et al. 1999, Baule 2000, Flores et al. 2002). The aim of the present study was to characterize bovine viral diarrhea virus isolates from cattle affected by different clinical syndromes in Brazil by partial nucleotide sequencing of the 5'-UTR region.

\section{MATERIALS AND METHODS}

Twelve BVDV field strains isolated in tissue culture (Flores et al. 2005) and seven BVDV field isolates directly detected by reverse transcription followed by PCR (RT-PCR) in clinical samples (Cortez et al. 2005b) were submitted to partial sequencing of 5'UTR region for genotyping and subgenotyping.

RNA extraction was performed using TRIzol reagent (Invitrogen). The RNA was reverse-transcribed with the Moloney Murine Leukemia Virus-Reverse Transcriptase using random primers (MMLV-RT; Invitrogen ${ }^{\mathrm{TM}}$ ). Amplification of a 5'-UTR fragment was obtained with the primers P1 and P2 described by Ridpath \& Bolin (1998). A hemi- nested PCR was carried out employing the primers P1 and PN2 (5' RCA CCC TWW CAG GCT GT 3') as internal primers.

Sequencing was carried out with primers P1 and PN2, using the Big Dye TM Terminator-cycle sequencing ready reaction kit (Applied Biosystems). Sequences were examined with the software PHRED (http:// bioinformatica.ucb.br/electro.html) for quality analysis of chromatogram readings. The sequences were accepted if their quality readings were equal to or higher than 20 . The consensus sequences were determined by the software CAP3 (http://bioinformatics.iastate.edu/aat/ sas.html) and the alignment was obtained with the aid of the software BioEdit (Hall 1999). The sequences described in Table 1 were used for comparison purposes. The presence of a phylogenetic signal was verified by the saturation in the curve of transition versus transversion calculated by the software DAMBE (Xia \& Xie 2001).

In order to determine the evolutionary model of nucleotide substitution for the group of sequences analyzed, likelyhood-ratio tests (Hueselsenbeck \& Rannala 1987) were used with the aid of the software ModelTest (Posadas \& Crandall 1988).

Utilizing the software Mega (Molecular Evolutionary Genetics Analysis) v.2.0 (Kumar et al. 2000), 55 taxa of 167 nucleotides, from a total of 358 nucleotides of 5'-UTR region, were analyzed by NeighborJoining (NJ) method. The values of the genetic distances and bootstraps were calculated. Bootstrap calculations were performed by the heuristic search method with 1000 copies.

Table 1. Pestivirus isolates, indicating accession number, reference, origin of the isolate and classification

\begin{tabular}{|c|c|c|c|c|}
\hline Isolates & $\begin{array}{c}\text { Gene Bank } \\
\text { Access Number }\end{array}$ & References & Origin of strains & BVDV Subgenotype \\
\hline EVI 006 & Not available & Gil 1998 & Rio Grande do Sul/Brazil & 1a \\
\hline INTA 5 & Not available & Gil 1998 & Argentina & 1a \\
\hline $126 / 1$ & Not available & Gil 1998 & Rio Grande do Sul/Brazil & $1 \mathrm{a}$ \\
\hline NADL & M31182 & Collet et al. 1998 & USA & $1 \mathrm{a}$ \\
\hline akt1 & AY 443029 & Jones et al. 2004 & Argentina & 1a \\
\hline 68.88 & AF 244962 & Jones et al. 2001 & Argentina & $1 \mathrm{a}$ \\
\hline UFSM 1 & Not available & Gil 1998 & Rio Grande do Sul/Brazil & $1 b$ \\
\hline UFSM 2 & Not available & Gil 1998 & Rio Grande do Sul/Brazil & $1 b$ \\
\hline IBSP2 & Not available & Gil 1998 & São Paulo/Brazil & $1 b$ \\
\hline IBSP4 & Not available & Gil 1998 & São Paulo/Brazil & $1 \mathrm{~b}$ \\
\hline INTA 1 & Not available & Gil 1998 & Argentina & $1 b$ \\
\hline INTA 4 & Not available & Gil 1998 & Argentina & $1 \mathrm{~b}$ \\
\hline INTA 6 & Not available & Gil 1998 & Argentina & $1 b$ \\
\hline $126 / 8$ & Not available & Gil 1998 & Rio Grande do Sul/Brazil & $1 b$ \\
\hline $126 / 14$ & Not available & Gil 1998 & Rio Grande do Sul/Brazil & $1 \mathrm{~b}$ \\
\hline $153 / 1$ & Not available & Gil 1998 & Rio Grande do Sul/Brazil & $1 b$ \\
\hline Strain NY-1 & L32879 & Pellerin et al. 1994 & USA & $1 \mathrm{~b}$ \\
\hline $3 \mathrm{P}$ & AF244968 & Jones et al. 2001 & Argentina & $1 b$ \\
\hline 66.1 & AF244953 & Jones et al. 2001 & Argentina & $1 b$ \\
\hline SE 6530 & 1580751 & GenBank & Not informed & $2 \mathrm{a}$ \\
\hline $97 / 730$ & AF026770 & GenBank & New Zealand & $2 a$ \\
\hline SW-90 & AB003622 & Nagai et al. 1998 & Japan & $2 a$ \\
\hline Strain 890 & U18059 & Ridpath \& Bolin 1995 & USA & $2 a$ \\
\hline 167237 & U65055 & Vicek et al. 1997 & Wales & $2 a$ \\
\hline 1373 & AF145967 & Ridpath et al. 2006 & USA & $2 a$ \\
\hline VM 97 & Not available & Gil 1998 & Rio Grande do Sul/Brazil & $2 b$ \\
\hline SV63 & Not available & Gil 1998 & Rio Grande do Sul/Brazil & $2 b$ \\
\hline Soldan & U94914 & Canal et al. 1998 & Rio Grande do Sul/Brazil & $2 b$ \\
\hline 34B & AF 244952 & Jones et al. 2001 & Argentina & $2 b$ \\
\hline D32_00 HoBi & AY489116 & Schirrmeier et al. 2004 & Brazil & Atypical pestivirus \\
\hline Rudolph & AB122086 & GenBank & Not informed & Border Disease Virus (BDV) \\
\hline Casimir & AB 122085 & GenBank & Not informed & BDV \\
\hline CSFV/MP & AY182247 & GenBank & Not informed & Classic Swine Fever (CSFV) \\
\hline INB-03 & DQ191444 & GenBank & India & CSFV \\
\hline unnamed & AY306121 & GenBank & Not informed & CSFV \\
\hline CSFV/LAP & AY182248 & GenBank & Not informed & CSFV \\
\hline
\end{tabular}


Two-sample t Tests were carried out using the software MINITAB ${ }^{\circledR}$ to compare the average genetic distances between each group of BVDV sequences. The sequences used for this analyze were grouped according to the results obtained with the phylogenetic analysis (Fig 1). The group BVDV-1 contains the average genetics distances of the sequences of genotype BVDV-1, the group BVDV-2, is formed by isolates belonging to the genotype BVDV-2, the Atypical Pestivirus holds the atypical pestivirus sequences. The External Group contains the sequences of Border Disease and Classical Swine Fever Virus. Values for $\mathrm{p} \leq 0.05$ were considered statistically significant.

\section{RESULTS}

The analysis of the phylogenetic signal showed that saturation between transition and transversion did not occur in the sequences utilized, indicating that these may be used in phylogenetic reconstruction.

The most appropriate evolutionary model of nucleotide substitution for the group of sequences analyzed was the Kimura two-parameter model.

Eleven isolates had their genotypes determined as BVDV-1 (eight as subgenotype BVDV-1a and three as subgenotype BVDV$1 \mathrm{~b}$ ) and six as BVDV-2 (four subgenotypes BVDV-2b and two as subgenotype BVDV-2a). Two isolates formed a group with the $\mathrm{D} 32 / 00 \_\mathrm{HoBi}$, an atypical pestivirus isolates from Brazilian foetal bovine serum (Table 2, Fig. 1 ).

The statistic analysis, using two-sample t Test, of the genetic distances for the sequences grouped in BVDV-1, BVDV-2, Atypical Pestivirus and External Group showed that only the average values of BVDV-1 x BVDV-2 were not statistically significant, meaning that the average values of the genetic distances of these groups are not different. The average values between the other groups BVDV-1 x Atypical Pestivirus, BVDV-1 x External Group, BVDV-2 x Atypical Pestivirus, BVDV-2 x External Group, Atypical Pestivirus $x$ External Group were statistically significant $(p<0.05)$.

It was not possible to establish any spatial, temporal and/or symptomatic statistical correlation with specific genotypes or subgenotypes (Table 2).

\section{DISCUSSION}

The genotypes and subgenotypes obtained in this study by partial nucleotide sequencing of 5'-UTR region (Fig.1, Table 2) confirm the results reported by other authors (Canal et al. 1998, Gil et al. 1998, Flores et al. 2002, 2005) that demonstrated the presence of BVDV-1 and BVDV-2 in various Brazilian states. The finding of subgenotypes BVDV-1a and BVDV-1b corroborates the data by Gil (1998) and Gil et al. (1998). Although no other BVDV-1 subgenotypes have been evidenced in the present study, Vilcek et al. (2004) described the existence of the subgenotype BVDV$1 d$ in Brazil.

The wide distribution of the clinical manifestations for the two genotypes (Table 2) supports others studies that verified the pathogenic and genetic diversity associated with Brazilian isolates (Gil et al. 1998, Flores et al. 2002, 2005).

Within subgenotype BVDV-1a, the isolates 132, EVI006, UFSM 3 and $1 / 5$ displayed $100 \%$ identity. This sequence was found in isolates from the State of Rio Grande do Sul (EVI006) in the 90's, and in the States of Minas Gerais (1/5) and Rio Grande do
Sul (132 and UFSM3) in 2004. In Paraná State, in 2003, a sister group was observed (303). The isolate 3/4 from State of Mato Grosso do Sul formed a sister-group with the isolates 303, 132, UFSM3, 1/5, EVI006. The results suggest that viruses showing this genetic profile are circulating in the regions South, Southeast and Central-Western Brazil. The transmission between the States could have occurred through of trade infected animals, of cryopreserved vehicles like semen and embryos as well in artificial reproductive techniques (Lindberg \& Houe 2005).

The most isolates $(278,3 / 4303$, UFMS3 and 1/5) formed a cluster predominantly connected to reproductive manifestation that could not be showed in the sister-group $(216,663$; Fig. 1 , Table 2) and was presented in the States of Rio Grande do Sul, Paraná and Minas Gerais. Jones et al. (2004) suggested that isolates linked to reproductive disorders are more recent than enteric isolates.

The isolate IBSP4, obtained from clinical sample in 1995, in Ribeirão Preto, SP, formed a distinct group in relation to the others of subgenotype BVDV-1b, supported by a bootstrap value higher than 70. In the same year, in the city of Jaboticabal, SP, distant from Ribeirão Preto by $50 \mathrm{~km}$, an isolate of the sister group (IBSP2) was obtained, showing that, in the same year and in herds located a few kilometers apart, different genetic types of the virus may circulate concomitantly.

Still regarding the subgenotype BVDV-1b, in 1996, similar nucleotide sequences were found in the isolates UFSM1, UFSM2, $126 / 14,153 / 1$, obtained from healthy bovine fetuses collected in slaughterhouses in different cities in the State of Rio Grande do Sul. In 2001, in Arroio dos Ratos, RS, a virus harboring a similar sequence (163) was isolated from an animal presenting respiratory and digestive signs. Different clinic manifestation in the other cluster $(390,395)$ could also be demonstrated (Fig.1, Table2).

Factors associated with host, the environment and agent can influence the clinical outcome of BVDV (Baker 1995, Hamers et al. 2001) and despite Jones et al. (2004) and Baule et al. (2001) related to subgenotypes BVDV-1b and BVDV-1d with respiratory disease, a correlation between BVDV genotypes and subgenotypes and clinical signs has not yet been evidenced (Ripath et al. 1994, Lettelie et al. 1999, Fulton et al. 2005).

Among the genotype BVDV-2, two were identified as subgenotype BVDV-2a and four as subgenotype BVDV-2b. Flores et al. (2002) and Vilcek et al. (2004) suggested that there is a possible geographic link between North America and subgenotype BVDV-2a, and between South America and subgenotype BVDV-2b.

In the present study, a wide range of clinic manifestation associated with of BVDV-2 isolates was observed ( Table 2). There were two subgroups of BVDV-2a circulating, the isolate 44 collected in State of São Paulo in 1997 clustered into same subgroup with United State of America, Wales, Japan, New Zealand isolates and a BVDV positive (323) gathered in 2004 that was segregated in a distinct subgroup. It would be necessary a larger number of isolates to verified if this subdivision correlates with traits epidemiology like time of isolation.

Brazilian isolates display a high antigenic variability and are different from North American vaccine strains and also may cau- 


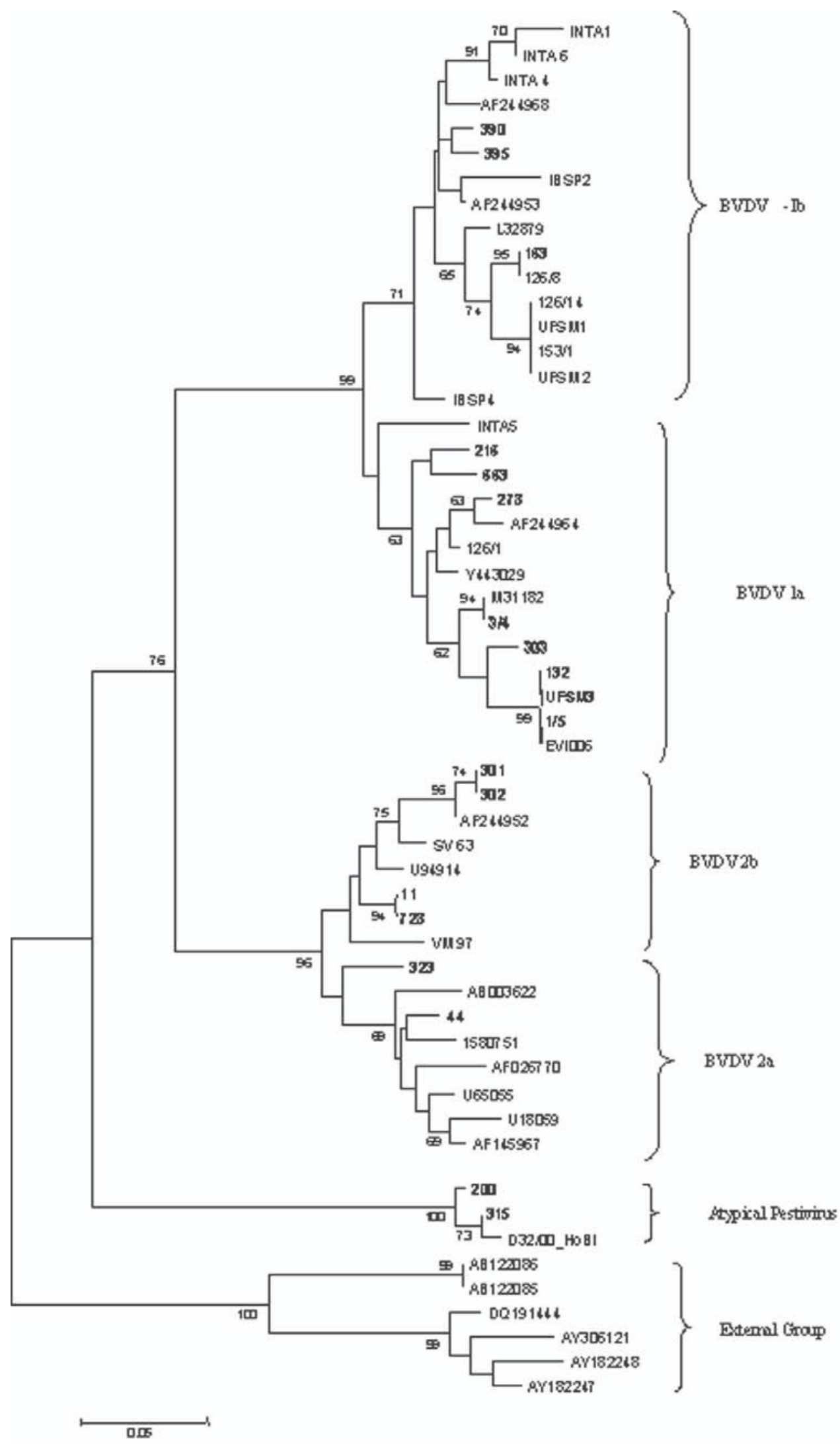

Fig.1. Phylogram produced by Neighbor-Joining (NJ) method with the aid of Kimura 2-parameter model for BVDV 5'-UTR region with Bootstrap values. 
Table 2. Genotyping results obtained by partial sequencing of a 5'-UTR Region in Brazilian BVDV isolates

\begin{tabular}{|c|c|c|c|c|}
\hline Isolates a & Year b & Condition/Clinical signs ${ }^{c}$ & Origin $\mathrm{d}$ & Subgenotype ${ }^{\mathrm{e}}$ \\
\hline UFSM3 $\mathrm{f}$ & 1997 & Healthy calf & Pelotas, RS & $1 \mathrm{a}$ \\
\hline $663^{f}$ & 2000 & Persistent respiratory disease & Tapejara, RS & $1 \mathrm{a}$ \\
\hline $1 / 5 \mathrm{~g}$ & 2002 & Aborted Foetus & Muriaé, MG & $1 \mathrm{a}$ \\
\hline $216^{\mathrm{f}}$ & 2002 & Persistent infection & Interior do RS & $1 \mathrm{a}$ \\
\hline $3 / 4^{g}$ & 2004 & Respiratory disease & Rondonópolis, MT & $1 \mathrm{a}$ \\
\hline $303^{f}$ & 2003 & Aborted foetus & Londrina, PR & $1 \mathrm{a}$ \\
\hline $132^{\mathrm{f}}$ & 2004 & Aborted foetus & São Martinho, RS & $1 \mathrm{a}$ \\
\hline $278^{f}$ & 2004 & Aborted foetus & São Vicente do Sul, RS & $1 \mathrm{a}$ \\
\hline $395^{f}$ & - & Aborted foetus & Londrina, PR & $1 \mathrm{~b}$ \\
\hline $163^{\mathrm{f}}$ & 2000 & Respiratory and digestive & Arroio dos Ratos, RS & $1 \mathrm{~b}$ \\
\hline $390^{g}$ & 2002 & Diarrhea & Porecatu, PR & $1 \mathrm{~b}$ \\
\hline $44^{\mathrm{g}}$ & 1997 & Aborted foetus & Batatais, SP & $2 a$ \\
\hline $323^{f}$ & 2004 & Gastrointestinal & Porto Alegre, RS & $2 a$ \\
\hline $728^{\mathrm{f}}$ & 2002 & Gastrointestinal & RS & $2 \mathrm{~b}$ \\
\hline $11 \mathrm{f}$ & 2003 & Gastrointestinal & Cruz Alta, RS & $2 b$ \\
\hline $301^{\mathrm{f}}$ & 2003 & Persistent infection & Carambeí, PR & $2 b$ \\
\hline $302^{f}$ & 2003 & Persistent infection & Carambeí, PR & $2 b$ \\
\hline $200^{g}$ & 2002 & Aborted foetus & São Sebastião da Grama, SP & Atypical Pestivirus \\
\hline $315^{g}$ & 2004 & Aborted foetus & Tambaú, SP & Atypical Pestivirus \\
\hline
\end{tabular}

a Isolate, b Year of isolation in cell culture or detection by PCR, c Clinical symptoms associated to the isolate, d Place of isolate collection, RS: Rio Grande do Sul, PR: Paraná, SP: São Paulo, MG: Minas Gerais, MT: Mato Grosso do Sul, e Genotype/Subgenotype obtained by partial sequencing of a 5'-UTR region, ${ }^{\mathrm{f}}$ viral isolations, $\mathrm{g}$ virus diagnosed by PCR.

se false-negative results in serologic diagnosis as the serumneutralization test (Flores et al. 2000).

The finding of two isolates (200 and 315) that grouped together with D32/00_HoBi isolate (Schirrmier et al. 2004) is supported by phylogenetic reconstruction, by high bootstrap values that separate the ramifications of the various groups (Fig.1) and by statistic analysis, that shows that there is a significant difference between the average values of the genetic distances for group D32/00_HoBi and the other groups. The D32/00 HoBi isolate was first described in Germany, in 2004, as a contaminant of Brazilian fetal bovine serum and displays antigenic and genetic characteristics that are distinct from other Pestivirus. These data suggest that these isolates may belong to a recently described new species within the genus Pestivirus. In the animal experiment, inoculated calves did not show clinical signs (Schirrmier et al. 2004). The two isolates described in this study, 200 and 315, were obtained from bovine foetuses aborted in 2002 (200) in São Sebastião da Grama, and in 2004 (315) in Tambaú, both cities located in the State of São Paulo, about 100 $\mathrm{km}$ apart from each other, a fact suggesting that these isolates were probably circulating among cattle and causing reproductive disorders in the region.

Despite the relatively small number of isolates analyzed, yet the source of the isolates being mostly from Central-Southern Brazil, the diversity observed among Brazilian BVDV isolates obtained from different clinical syndromes associates the antigenic differences of several genotypes, subgenotypes and a presence of new species of Pestivirus causing reproductive disorders may contribute to diagnostic and vaccination failures, thus hampering disease control measures. These results also point out to the need for permanent viral monitoring and genetic and antigenic characterization of the isolates throughout the country.
Acknowledgements.- To Dr. José Paulo G. Leite at Instituto Oswaldo Cruz (FIOCRUZ/RJ) for valuable comments and suggestions. This study was supported by FAPESP (Proc. 01/10155-4).

\section{REFERENCES}

Baker J.C. 1995. The clinical manifestation of bovine viral diarrhea infection. Bovine Viral Diarrhea Virus. Vet. Clin. North Am., Food Anim. Pract.. 11:425-446.

Baule C. 2000. Molecular characterization of Bovine Viral Diarrhoea Virus, an important pathogen of cattle. Doctoral thesis, Swedish University of Agricultural Sciences, Uppsala, p.49.

Baule C., Vuuren M. van, Lowings J.P. \& Belák S. 1997. Genetic heterogeneity of bovine viral viruses isolated in Southern Africa. Virus Res. 52:205-220.

Baule C., Kulcsar G., Belak K., Albert M., Mittelholzer C., Soos T., Kucsera L. \& Belak S. 2001. Pathogenesis of primary respiratory disease induced by isolates from a new genetic cluster of bovine viral diarrhea virus type I. J. Clin. Microbiol. 39(1):146-53.

Canal C.W., Strasser M., Hertig C., Masuda A. \& Peterhans E.1998. Detection of antibodies to bovine viral diarrhea virus (BVDV) and characterization of genomes of BVDV from Brazil. Vet. Microbiol. 63:85-97.

Collett M.S., Larson R., Gold C., Strick D., Dennis K., Anderson D.K. \& Purchio A.F. 1988. Molecular cloning and nucleotide sequence of the pestivirus bovine viral diarrhea virus. Virology 165(1):191-199.

Cortez A., Heinemann M.B., Soares R.M., Castro A.M.M.G., Leite R.C. \& Richtzenhain L.J. 2005a. Sensibilidade analítica de uma hn-nested para o vírus da Diarréia Viral Bovina em amostras clínicas experimentalmente contaminadas. VI Congresso de Buiatria, Búzios, RJ, 25-28 de maio de 2005. Meio digital. htpp://www.buiatria.org.br. Disponível em 28.05.2005.

Cortez A., Heinemann M.B., Castro A.M.M.G., Scarcelli E., Genovez M.E., Vasconcellos S.A., Alfieri A.A. \& Richtzenhain L.J. 2005b. Emprego da PCR no diagnóstico direto de enfermidades causadoras de distúrbios reprodutivos em bovinos e bubalinos. Meio digital. htpp:// www.buiatria.org.br. Disponível em 28.05.2005.

Flores E.F., Weiblen R., Gil L.H.V.G., Tobias F.L., Lima M., Garcez D.C \& Botton S.A. 2000. Diversidade antigênica de amostras do vírus da diarréia viral bovina isoladas no Brasil: implicações para o diagnóstico e estratégias de imunização. Arq. Bras. Med. Vet. Zootec. 52(1):11-17. 
Flores E.F., Ridpath J.F., Weiblen R., Vogel F.S.F. \& Gil L.H.V.G. 2002. Phylogenetic analysis of Brazilian bovine viral diarrhea virus type 2 (BVDV-2) isolates: evidence for a subgenotype within BVDV-2. Virus Res. 87:51-60.

Flores E.F., Weiblen R., Vogel F.S.F, Roehe P.M., Alfieri A.A. \& Pituco E.M. 2005. A infecção pelo Vírus da Diarréia Viral Bovina (BVDV) no Brasil: histórico, situação atual e perspectivas. Pesq. Vet. Bras. 25(3):125-134.

Fray M.D., Paton D.J. \& Alenius S. 2000. The effects of bovine viral diarrhoea virus on cattle reproduction in relation to disease control. Anim. Reprod. Sci. 60/61:615-627.

Fulton R.W., Ridpath, J.f., Ore S., Confer A.W., Saliki J.T., Burge L.J. \& Payton M.E. 2005. Bovine viral diahrroea virus (BVDV) subgenotypes in diagnostic laboratory accessions: Distribution of BVDV-1a, 1b, and 2a subgenotypes. Vet. Microbiol. 111:35-40.

Gil L.H.V.G. 1998. Seqüenciamento, análise filogenética e caracterização de polipeptídeos não-estruturais de amostras do Vírus da Diarréia Viral Bovina (BVDV). Dissertação de Mestrado, Universidade Federal de Santa Maria, Santa Maria, Rio Grande do Sul. 69p.

Gil L.H.V.G., Botton S.A., Odeon S.A., Weber L., Weiblein R., Ridpath J.F. \& Flores E.F. 1998. Genotypic analysis of South America isolates of bovine viral diarrhea virus. Simpósio Internacional sobre Herpesvírus bovino (tipos 1 e 5) e Vírus da Diarréia Viral Bovina, Santa Maria, RS, p.177. (Resumo)

Hall T.A. 1999. BioEdit: a user-friendly biological sequence alignment editor and analysis program for Windows 95/98/NT. Nucl. Acids. Symp. Ser. 41:95-98.

Hamers C., Dehan P., Couvreur B., Letellier C., Kerkhoes P. \& Pastoret P.-P. 2001. Diversity among bovine pestivirus. Vet. J. 161:112-122

Houe H. 1999. Epidemiological features and economical importance of bovine virus diarrhoea virus (BVDV) infections. Vet. Microbiol. 64:89-107.

Hueselsenbeck J.P. \& Rannala B. 1987. Phylogenetic methods come of age: testing hypothesis in evolucionary context. Science 276:227-32.

Jones L.R., Zandomeni R. \& Webwe L.E. 2001. Genetic typing of bovine viral diarrhea virus isolates from Argentina. Vet. Microbiol. 81:367-375.

Jones L.R., Cigliano M.M., Zandomeni R.O. \& Weber E.L. 2004. Phylogenetic analysis of bovine pestiviruses: testing the evolution of clinical symptoms. Cladistics 20(5):443-453.

Kumar S., Tamura K., Jakobsen I.B., Nei M. 2001. MEGA2: molecular evolutionary genetics analysis software. Bioinformatics 17(12):12441245.

Letellier C., Kerkhofs P., Wellwmans G. \& Vanopdenbosch E. 1999. Detection and genotyping of bovine diarrhea virus by reverse transcriptionpolymerase chain amplification of the 5'untranslated region. Vet. Microbiol. 64:155-167.

Lindeberg A. \& Houe H. 2005. Characteristics in the epidemiology of bovine viral diarrhea virus (BVDV) of relevance control. Prev. Vet. Med. 72:55-73
Meyer G., Rumenopf T. \& Thiel H.-J. 1989. Molecular cloning and nucleotide sequence of the genoma of hog cholera virus. Virology 171:555-567.

Nagai M., Sato M., Nagano H., Pang H., Kong X., Murakami T., Ozawa T. \& Akashi H. 1998. Nucleotide sequence homology to bovine viral diarrhea virus 2 (BVDV-2) in the $5^{\prime}$ untranslated region of BVDVs from cattle with mucosal disease or persistent infection in Japan. Vet. Microbiol. 60(24):271-276.

Pellegrin C., Van den Hurk J., Lecomte J. \& Tijssen P. 1994. Identification of a new group of bovine viral diarrhea virus strains associated with severe outbreaks and high mortalities. Virology 203:260-268.

Posadas J. \& Crandall K.A. 1988. Modeltest: testing the model of DNA substitution. Bioinformatics 14(9):817-18.

Ridpath J.F., Bolin S.R. \& Dubovi E.J. 1994. Segregation of Bovine Viral Diarrhea Virus into genotypes. Virology 205:66-74.

Ridpath J.F. \& Bolin S.R. 1995. The genomic sequence of a virulent bovine viral diarrhea virus (BVDV) from the type 2 genotype: detection of a large genomic insertion in a non-cytopathic BVDV. Virology 212 (1):3946

Ridpath J.F. \& Bolin S.R. 1998. Differentiation of types 1a, 1b and 2 bovine viral diarrhea virus (BVDV) by PCR. Mol. Cell. Probes 12(2):101-106.

Ridpath J.F., Neill J.D., Vilcek S., Dubovi E.J. \& Carman S. 2006. Multiple outbreaks of severe acute BVDV in North America occurring between 1993 and 1995 linked to the same BVDV2 strain. Vet. Microbiol. 114(34):196-204.

Sandvick T., Paton D. \& Lowings P.J. 1997. Detection and identification of ruminant and porcine pestivirus by nested amplification of 5 'untranslated cDNA regions. J. Virol. Methods 64:43-56.

Schirrmeier H., Strebelow G., Depner K., Hoffman B. \& Beer M. 2004. Genetic and antigenic characterization of an atypical pestivirus isolate, a putative member of a novel pestivirus species. J. Gen. Virol. 85:36473652

Tajima M., Frey H., Osamu, Y., Maede Y., Moeninig V., Scholz H. \& GreiserWilke I. 2001. Prevalence of genotypes 1 and 2 of bovine viral diarrhea virus in Lower Saxony, Germany. Virus Res. 76:31-42.

Vilcek S., Nettleton P.F., Paton D.J. \& Belak S. 1997. Molecular characterization of ovine pestiviruses. J. Gen. Virol. 78(Pt 4):725-735

Vilcek S., Paton D.J., Durkovic B., Strojny L., Ibata G., Moussa A., Loitsch A., Rossmanith W., Vega S., Scicluna M.T. \& Paifi V. 2001. Bovine viral diarrhoea virus genotype 1 can be separated into at least eleven genetic groups. Arch. Virol. 146(1):99-115.

Vilcek S., Durkovic B., Kolesarova M., Greiser-Wilke I. \& Paton D. 2004. Genetic diversity of international bovine viral diarrhoea virus (BVDV) isolates: identification of a new BVDV-1 genetic group. Vet. Res. 35:609615.

Xia X. \& Xie Z. 2001. DAMBE: Data analyses in molecular biology and evolution. J. Heredity 92:371-373. 